\title{
PENGARUH FINANCIAL SLACK TERHADAP KINERJA PERUSAHAAN STUDI PADA PERUSAHAAN-PERUSAHAAN MANUFAKTUR YANG TELAH GO PUBLIC DI BURSA EFEK INDONESIA
}

\author{
Donalson Silalahi
}

ABSTRACT

The relationship between financial slack with the company's performance is not clear. Therefore, this issue more interesting to study. Financial slack can be grouped into two types: available slack and potential slack. Therefore, this study is intended to clarify the effect of available slack and potential slack to company performance.

To achieve this aim, used a linear regression equation. The study focused on companies listed on Indonesia Stock Exchange by using purposive sampling technique in sampling research so that the sample size were 112 companies. The data used in this research is secondary data with observations in the period 2008-2010. To explain the effect of financial slack on the performance of companies used the $t$ and F test with a by 10 percent.

Based on the analysis and discussion, some conclusions as follows: Firstly, available slack and potential slack have significant negative effect on the performance of the company. Second, the greater the slack of the company, there is a tendency that corporate leaders will tend to use the slack to fulfill its interests.

Based on the above conclusions, some suggestions as follows: Firstly, if the company's performance would be improved, financial slack needs to be lowered to a level that is needed. Second, the results of this study can be used as a basis for regulators to make regulations to improve the quality of corporate governance of the corporation. Third, further research is needed by differentiating the sample of companies over companies that implement good corporate governance and corporate governance is not good.

Key words: Available Slack, Potential Slack, Performance, Corporate Governancee.

\section{PENDAHULUAN}

Pasar modal Indonesia mulai diaktifkan kembali sejak tahun 1987-an. Dalam kurun waktu selama 34 tahun, perusahaan-perusahaan yang telah mengemisikan sahammnya di pasar modal Indonesia menunjukkan peningkatan yang pantastis, dari 24 perusahaan tahun 1987 menjadi 428 perusahaan tahun 2011. Fenomena ini dapat dimaknai semakin bertambahnya perusahaan-perusahaan di Indonesia yang melakukan pemisahan fungsi pengelola dan kepemilikan.

Pemisahan fungsi pengelola dan kepemilikan perusahaan akan menimbulkan masalah agensi (Jensen dan Meckling: 1976). Oleh karenanya, untuk menjaga keberlangsungan operasi perusahaan, masalah agensi tersebut perlu diatasi melalui mekanisme corporate governance dalam rangka meningkatkan kinerja perusahaan.

Dewasa ini, konsep corporate governance telah banyak diperbincangkan sebab pelaksanaan corporate governance yang tidak baik menjadi salah satu faktor penyebab terjadinya krisis keuangan dan skandal-skandal keuangan/akuntansi di perusahaan-perusahaan besar. Oleh karenanya, dengan mengimplementasikan corporate governance, misalnya melalui perampingan organisasi akan menghasilkan efisiensi ekonomi. Ide dasar dibalik implementasi perampingan organisasi ini adalah dengan mengeliminasi organizational slack akan meningkatkan kinerja perusahaan.

Dewasa ini, literatur corporate governance telah memusatkan perhatian terhadap isu slack dalam kaitannya dengan kinerja perusahaan. Slack menggambarkan sumberdaya yang dimiliki 
oleh suatu organisasi melebihi sumberdaya yang dibutuhkan (Nohria dan Gulati: 1996). Oleh karenanya, perusahaan dengan sejumlah slack mengakibatkan masalah alokasi sumberdaya menjadi berkurang (Daniel dan Lohrke: 2004) serta dapat memperbaiki pengelolaan informasi dan dengan demikian ketergantungan antara unit-unit organisasi menjadi berkurang (Galbraith: 1973).

Menurut Lee (2012), hubungan antara organizational slack dengan kinerja perusahaan tidak jelas. Artinya, issu ini semakin menarik untuk diteliti, terutama yang berhubungan dengan financial slack. Berbagai penelitian tentang financial slack dalam kaitannya dengan kinerja perusahaan telah banyak dilakukan di negara-negara asing. Hasil-hasil penelitian yang menunjukkan bahwa slack memiliki hubungan yang positip dengan kinerja perusahaan (Mohr: 1969; Carter: 1971; Bourgeois: 1981; Latham. dan Braun: 2008). Hasil penelitian yang dilakukan oleh Litschert dan Bonham (1978); Simon (1997); dan Yasai-Ardekani (1986) menemukan bahwa slack tidak memiliki hubungan dengan kinerja perusahaan atau slack memiliki hubungan yang negatip dengan kinerja perusahaan.

Selanjutnya, Bergh dan Lawiess (1998) melaporkan bahwa available slack berpengaruh positip terhadap kinerja perusahaan dan potential slack berpengaruh negatip terhadap kinerja perusahaan. Lee (2011) melaporkan bahwa financial slack berpengaruh positip terhadap kinerja perusahaan. Lebih lanjut, Lee (2012) melaporkan bahwa financial slack berhubungan negatip dengan kinerja perusahaan di U.S. sementara di negara Inggris bahwa financial slack berhubungan positip dengan kinerja perusahaan.

Penelitian-penelitian tersebut di atas dilakukan di pasar modal asing dan memberikan kesimpulan yang berbeda-beda sehingga semakin menarik untuk diteliti kembali pengaruh financial slack terhadap kinerja perusahaan yang difokuskan pada perusahaan-perusahaan manufaktur yang terdaftar di. Bursa Efek Indonesia.

Berdasarkan paparan tersebut, maka penelitian ini dimaksudkan untuk menjelaskan pengaruh available slack dan potential slack terhadap kinerja perusahaan. Untuk mencapai maksud tersebut, maka dalam penelitian ini dipergunakan persamaan regressi linier berganda sebagai alat analisis baik sebelum maupun sesudah data dikelompokkan.

\section{Financial Slack}

\section{TINJAUAN PUSTAKA}

Dalam literature organisasi, slack memiliki berbagai bentuk. Bourgeois dan Singh (1983) mengelompokkan slack berdasarkan mudah tidaknya slack didapatkan, yaitu: available slack, recoverable slack, dan potential slack. Dari ketiga kategori tersebut, slack dapat juga dikelompokkan kedalam dua bentuk yang ekstrim, yaitu: available slack dan potential slack (Lee: 2012).

Available slack berhubungan dengan sumberdaya ekstra yang dimiliki oleh suatu perusahaan sehingga manajer menjadi lebih fleksibel dalam melaksanakan aktivitasnya. Misalnya, tersedianya kas dan surat-surat berharga merupakan bentuk available slack. Berbagai penelitian empiris di bidang keuangan mempergunakan current ratio sebagai proxy dari available slack (Lee: 2011; Lee: 2012).

Potential slack berhubungan dengan sumberdaya yang dihasilkan dimasa depan melalui perubahan lingkungan ekonomi. Misalnya, kenaikan modal potensial perusahaan melalui kenaikan harga saham di pasar modal menggambarkan potential slack. Berbagai penelitian empiris di bidang keuangan mempergunakan leverage ratios seperti the ratio of debt to equity sebagai proxy dari potential slack (Lee: 2011; Lee: 2012). Jika rasio utang dengan ekuitas mengalami penurunan, hal ini menggambarkan bahwa pembayaran kewajiban dimasa depan 
juga turun sehingga potensial bagi outsiders (creditors) mempengaruhi kebijakan manager. Sebaliknya, kenaikan nilai rasio utang dengan ekuitas menunjukkan penurunan tingkat potential slack.

\section{Resource-based dan Agency Theory}

Menurut Lee (2011), pada dasarnya ada 2 (dua) teori yang berhubungan dengan slack, yaitu: resource-based theory dan agency theory. Dampak slack terhadap kinerja perusahaan pada dasarnya dielaborasi dari studi-studi perilaku organisasi, yaitu: resourced-based theory dan behavioral theory of the firm. Kedua teori tersebut memandang bahwa financial slack sebagai sarana yang bernilai untuk keberlangsungan hidup serta berperan penting dalam meningkatkan kinerja suatu perusahaan.

Resourced-based theory dimulai dengan suatu konsep bahwa sumberdaya yang dimiliki sangat penting dalam menghasilkan barang dan jasa (Pensore: 1959). Resources-based theory menekankan pada sumberdaya khusus yang dimiliki oleh suatu perusahaan dan kemampuannya mempergunakan sumberdaya tersebut dalam memperoleh keunggulan bersaing.

Resorce-based theory juga mengklaim bahwa sumberdaya yang bernilai sangat dibutuhkan perusahaan dan dengan mempergunakan sumberdaya tersebut secara efisien dan efektif akan diperoleh keunggulan kompetitif yang berkelanjutan, dan sebagai konsekuensinya akan menghasilkan keuntungan yang substansial. Lebih lanjut, Lee (2011) mengemukakan bahwa berdasarkan resourced-based dan behavioral theory of the firm, bahwa financial slack berperan dalam meningkatkan kinerja suatu perusahaan dengan alasan bahwa: (1) slack sebagai alat penahan goncangan (shock absorber), (2) slack sebagai alat untuk memecahkan konflit (a tool for conflict resolution), dan (3) slack sebagai fasilitator innovasi (facilitator of innovation).

Berdasarkan ketiga alasan tersebut dapat dikemukkan bahwa financial slack berdampak positip terhadap kinerja perusahaan. Hubungan positip tersebut juga didukung oleh finance theory. Perusahaan membutuhkan sumberdaya dalam mengerjakan projek-projek baru yang dijelaskan dalam pecking order theory (Myers: 1984; Myers dan Maljuf (1984). Perusahaanperusahaan mempergunakan sumber dana internal untuk melaksanakan projek-projek baru dan menguntungkan. Teori tersebut dengan jelas mengemukakan bahwa pembiayaan internal merupakan sumber utama dalam membiayai projek-projek inovatif dalam kondisi informasi asimetris sehingga perusahaan enggan mempergunakan sumber dana eksternal dalam membiayai projek-projek yang baru, sebab pembiayaan eksternal mengakibatkan masalah adverse selection di pasar modal sehingga pembiayaan internal menjadi lebih murah bila dibandingkan dengan pembiayaan eksternal. Oleh karenanya, kegiatan-kegiatan yang inovatif lebih tepat dibiayai melalui kegiatan internal financial slack.

Konsep tersebut didukung oleh hasil-hasil penelitian yang dilakukan oleh Mohr (1969); Carter (1971); Bourgeois (1981); Latham dan Braun (2008); Lee (2011) yang menunjukkan bahwa financial slack berdampak positip terhadap kinerja perusahaan.

Di samping resource-based theory, dampak financial slack terhadap kinerja perusahaan juga dapat dijelaskan dengan mempergunakan agency theory. Menurut teori agensi bahwa slack dipandang sebagai biaya yang tidak diperlukan perusahaan (unnecessary cost to firm). Oleh karenanya, berdasarkan teori tersebut dapat dikemukakan bahwa financial slack berpengaruh negatip terhadap kinerja suatu perusahaan. Selanjutnya, teori corporate governance dari perspektif agensi mengklaim bahwa dengan mengeliminasi slack akan membantu perusahaan menurunkan biaya-biaya yang tidak penting, artinya tingkat efisiensi semakin tinggi sehingga kinerja perusahaan naik. 
Semenjak Jensen dan Meckling (1976) mengemukakan masalah corporate governance dengan mengembangkan teori struktur kepemilikan perusahaan dalam perspektif teori agensi, corporate governance telah dipelajari dalam kerangka kerja teori agensi. Dalam pandangan ini, karakteristik utama perusahaan adalah konflik kepentingan antara shareholders dan managers sebagai konsekuensi dari pemisahan ownership dan control (Berle dan Means: 1932).

Shareholders dan managers memiliki tujuan yang berbeda-beda, dimana shareholders bertujuan meningkatkan nilai perusahaan sementara managers mengutamakan kepentingan mereka, seperti: meningkatkan power dan growth. Oleh karenanya, untuk menyelaraskan kepentingan antara shareholders dengan managers, maka mekanisme corporate governance diperlukan untuk memonitoring manajemen. Menurut pandangan ini bahwa memonitor manajemen dengan efektif akan mengakibatkan kinerja perusahaan semakin baik disebabkan biaya agensi perusahaan semakin rendah. Misalnya, aktivitas-aktivitas yang dilakukan oleh large sharegolders, independent directors dan institutional investor merupakan bentuk mekanisme corporate governance yang bernilai dalam memonitor manajemen.

Berdasarkan teori agensi bahwa manajer melakukan pemborosan sumberdaya demi memenuhi kepentingannya jika tidak ada mekanisme tatakelola perusahaan yang efektif. Dengan demikian dapat dikemukakan bahwa slack yang semakin besar mengakibatkan manajer kurang bekerja keras dan membiayai proyek-proyek yang menguntungkan. Oleh karena itu, diprediksi bahwa financial slack berdampak negatip terhadap kinerja perusahaan, sebab slack mendorong manajer melakukan aktivitas untuk memenuhi keinginannya dan tentu merupakan pengeluaran bagi shareholders sehingga dapat membahayakan kinerja perusahaan.

Berdasarkan paparan tersebut dapat dikemukakan bahwa financial slack berdampak negatip terhadap kinerja perusahaan. Konsep tersebut didukung oleh hasil-hasil penelitian yang dilakukan oleh Lee (2012) melaporkan bahwa financial slack berhubungan negatip dengan kinerja perusahaan di U.S.

\section{METODE PENELITIAN}

Dalam penelitian ini, variabel yang diteliti terdiri dari: Kinerja Perusahaan (KP), Available Slack (AS), dan Potential Slack (PS). Kinerja Perusahaan (KP) sebagai variabel dependen dimanifestasikan oleh return on assets, yaitu, rasio antara laba bersih dengan jumlah harta. Available slack (AS) sebagai variabel independen pertama dimanifestasikan oleh rasio lancar, yaitu perbandingan antara harta lancar dengan utang lancar, Potential Slack (PS) sebagai variabel independen yang kedua dimanifestasikan oleh rasio leverage, yaitu perbandingan antara utang dengan ekuitas.

Populasi dalam penelitian ini adalah semua perusahaan-perusahaan manufaktur yang terdaftar di Bursa Efek Indonesia pada akhir tahun 2010. Jumlah perusahaan-perusahaan manufaktur yang terdaftar di bursa efek Indonesia pada akhir tahun 2010 sebanyak 147 perusahaan. Dengan mengeliminasi perusahaan-perusahaan yang baru mengemisikan sahamnya pada periode penelitian dan perusahaan-perusahaan yang tidak memiliki data lengkap, maka sample size sebanyak 112 perusahaan. Dengan demikian, teknik pengambilan sampel dalam penelitian ini adalah mempergunakan teknik purposive sampling (Indriantoro dan Supomo: 1999).

Data yang dipergunakan dalam penelitian ini adalah data sekunder, yaitu: data kinerja perusahaan (KP) yang dimanifestasikan oleh return on assets, available slack (AS) yang dimanifestasikan oleh current ratio, dan potential slack (PS) yang dimanifestasikan oleh debt to equity ratio masing-masing perusahaan yang menjadi sampel penelitian dan terdaftar di Bursa 
Efek Indonesia pada 2010. Semua data tersebut didapatkan dari Indonesian Capital Market Directory Tahun 2011. Dengan demikian teknik pengambilan data adalah teknik dokumentasi.

Untuk menilai validitas empiris, penelitian ini mempergunakan data perusahaanperusahaan manufaktur yang telah go public selama 3 (tiga) tahun (2008 - 2010). Dengan demikian, jumlah pengamatan sebanyak 336 observasi (112 perusahaan). Model regressi berganda dipergunakan untuk menganalisis data, baik sebelum maupun sesudah data tersebut dikelompokkan sebagaimana ditunjukkan pada persamaan berikut:

$K P_{i t}=\beta_{0}+\beta_{1} A S_{i t}+\beta_{2} P_{i t}+\varepsilon$

Dimana KP merupakan kinerja perusahaan, AS merupakan available slack, PS meupakan potential slack, i merupakan perusahaan i, dan t merupakan periode waktu. Persamaan (1) dipergunakan untuk menguji sensitifitas Kinerja Perusahaan (KP) terhadap dampak financial slack. Tingkat sensitifitas kinerja perusahaan (KP) terhadap available slack (AS) ditunjukkan oleh koefisien regressi $\beta_{1}$. Tingkat sensitifitas kinerja perusahaan (KP) terhadap potential slack (PS) ditunjukkan oleh koefisien regressi $\beta_{2}$.

Persamaan (1) juga dipergunakan untuk menguji sensitifitas Kinerja Perusahaan (KP) terhadap dampak financial slack berdasarkan pengelompokan data. Untuk menjelaskan pengaruh financial slack terhadap kinerja perusahaan (KP) dipergunakan uji t dengan a sebesar 10 persen. Selanjutnya, untuk menjelaskan pengaruh secara serentak variabel bebas terhadap variabel tidak bebas dipergunakan uji $\mathrm{F}$ dengan a sebesar 10 persen serta untuk mengolah data dipergunakan program SPSS Version 18.

\section{Deskripsi Variabel Penelitian}

\section{HASIL PENELITIAN DAN PEMBAHASAN}

Deskripsi data yang berhubungan dengan variabel available slack (AS), potential slack (PS), dan kinerja perusahaan (KP) perusahaan-perusahaan manufaktur yang dimanipestasikan oleh current ratio, debt to equity ratio, dan return on assets selama tahun 2008 - 2010 dapat dilihat pada Tabel 1 berikut.

Tabel 1. Deskripsi Available Slack, Potential Slack, dan Kinerja Perusahaan Tahun 2008 - 2010

\begin{tabular}{|c|c|c|c|c|c|c|c|c|c|}
\hline \multirow[t]{2}{*}{ Ket } & \multicolumn{3}{|c|}{ Available Slack } & \multicolumn{3}{|c|}{ Poential Slack } & \multicolumn{3}{|c|}{ Kinerja Perusahaan } \\
\hline & 2008 & 2009 & 2010 & 2008 & 2009 & 2010 & 2008 & 2009 & 2010 \\
\hline Sampel & 112 & 112 & 112 & 112 & 112 & 112 & 112 & 112 & 112 \\
\hline Mean & 1.88 & 3.08 & 3.16 & 4.34 & 2.74 & 1.63 & .04 & 4.92 & 5.26 \\
\hline Median & 1.24 & 1.40 & 1.51 & 1.53 & 1.14 & 1.10 & 1.99 & 4.43 & 5.15 \\
\hline Std. Dev. & 2.84 & 10.94 & 9.49 & 20.45 & 8.15 & 3.00 & 9.84 & 6.96 & 6.62 \\
\hline Minimum & .010 & .19 & .19 & -4.59 & -12.14 & -4.41 & -43.89 & -15.46 & -16.43 \\
\hline Maximum & 27.50 & 113.71 & 85.41 & 216.26 & 75.61 & 27.06 & 17.67 & 25.88 & 27.50 \\
\hline
\end{tabular}

Sumber: Hasil Penelitian dan sudah Diolah.

Berdasarkan Tabel 1 dapat dikemukakan bahwa available slack (AS) yang dimanifestasikan oleh current ratio selama tahun 2008 - 2010 berada dalam kisaran 0,01 - 85,41. Rata-rata current ratio cenderung menunjukkan peningkatan yang diikuti oleh standar deviasi. Kondisi ini menggambarkan bahwa perusahaan-perusahaan manufaktur yang diamati cenderung memiliki available slack (AS) yang semakin tiggi. Potential slack (PS) yang dimanifestasikan oleh debt to equity ratio pada tahun 2008 - 2010 berada dalam kisaran -12,14 216,26. Rata-rata debt to equity ratio cenderung menunjukkan penurunan yang diikuti oleh standar deviasi. Kondisi ini menggambarkan bahwa perusahaan-perusahaan manufaktur yang diamati cenderung memiliki potential slack (PS) yang semakin rendah. Kinerja perusahaan (KP) yang dimanifestasikan oleh return on assets pada tahun 2008 - 2010 berada dalam kisaran -43,89 
- 27,50 persen. Rata-rata return on assets cenderung menunjukkan peningkatan yang diikuti oleh penurunan standar deviasi. Kondisi ini menggambarkan bahwa kinerja perusahaan-perusahaan manufaktur yang diamati cenderung semakin baik.

\section{Pengaruh Financial Slack Terhadap Kinerja Perusahaan.}

Rekapitulasi hasil perhitungan pengaruh available slack (AS) dan potential slack (PS) terhadap kinerja perusahaan (KP) dapat dilihat pada Tabel 2 berikut ini.

Tabel 2. Rekapitulasi Hasil Penelitian Pengaruh Available Slack dan Potential Slack Terhadap Kinerja Perusahaan

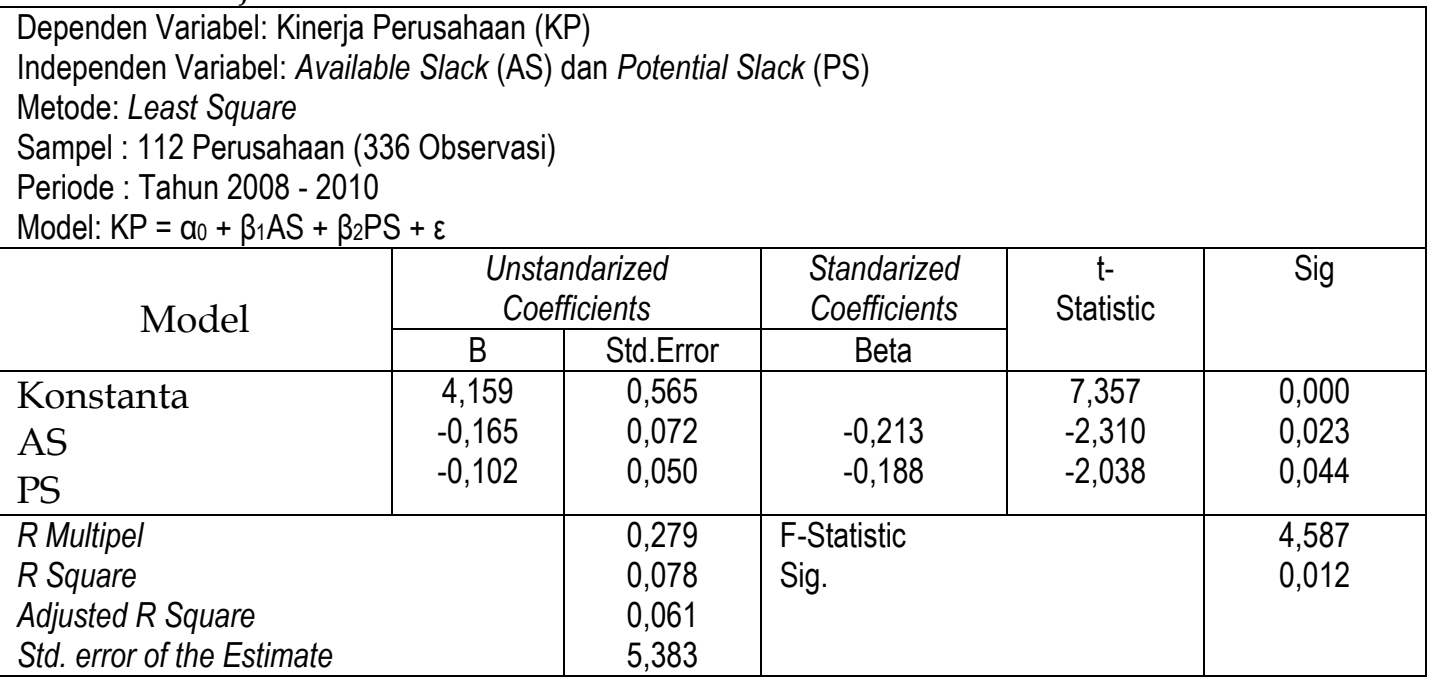

Sumber: Hasil Olahan Data Penelitian dengan Mempergunakan Program SPSS Version 18.

Berdasarkan Tabel 2 di atas, dapat dikemukakan bahwa nilai koefisien determinan sebesar 7,8 persen dengan nilai F-statistik adalah 4,587 dan probabilitas sebesar 0,012. Artinya, variabilitas kinerja perusahaan (KP) mampu dijelaskan oleh variabilitas available slack (AS) dan potential slack (PS) sebesar 7,8 persen dan sebanyak 92,2 persen lagi dijelaskan oleh variabel lain di luar model.

Nilai koefisien regressi variabel available slack (AS) sebesar - 0,165 dengan nilai t-satistik adalah -2,310 dan probabilitas sebesar 0,023. Dengan demikian dapat dikemukakan bahwa available slack (AS) berpengaruh negatip dan signifikan terhadap kinerja perusahaan (KP). Nilai koefisien regressi variabel potential slack (PS) sebesar - 0,102 dengan nilai t-satistik adalah -2,038 dan probabilitas sebesar 0,044. Dengan demikian dapat dikemukakan bahwa potential slack (PS) berpengaruh negatip dan signifikan terhadap kinerja perusahaan.

Model berikutnya adalah mempergunakan persamaan regressi linier dengan mengelompokkan data. Dalam literatur manajemen keuangan dikemukakan bahwa ukuran tradisional tentang besaran current ratio adalah 200 persen. Oleh karena itu, sampel penelitian ini dikelompokkan berdasarkan besaran current ratio menjadi dua kelompok. Kelompok pertama terdiri dari perusahaan-perusahaan yang memiliki current ratio dibawah 200 persen dan kelompok kedua adalah sampel yang memiliki current ratio diatas 200 persen.

Rekapitulasi hasil perhitungan pengaruh available slack (AS) dan potential slack (PS) terhadap kinerja perusahaan (KP) berdasarkan current ratio dapat dilihat pada Tabel 3 berikut ini.

Tabel 3. Rekapitulasi Hasil Penelitian Pengaruh Available Slack dan Potential Slack Terhadap Kinerja Perusahaan Berdasarkan Current Ratio (dibawah 200 Persen) 


\begin{tabular}{|c|c|c|c|c|c|}
\hline \multicolumn{6}{|c|}{$\begin{array}{l}\text { Dependen Variabel: Kinerja Perusahaan (KP) } \\
\text { Independen Variabel: Available Slack (AS) dan Potential Slack (PS) } \\
\text { Metode: Least Square } \\
\text { Sampel : } 88 \text { Perusahaan } \\
\text { Model: KP }=\alpha_{0}+\beta_{1} A S+\beta_{2} P S+\varepsilon\end{array}$} \\
\hline \multirow{2}{*}{ Model } & \multicolumn{2}{|c|}{ Unstandarized Coefficients } & $\begin{array}{l}\text { Standarized } \\
\text { Coefficients }\end{array}$ & $\begin{array}{c}\mathrm{t}- \\
\text { Statistic }\end{array}$ & Sig \\
\hline & $\mathrm{B}$ & Std.Error & Beta & & \\
\hline Konstanta & $-4,927$ & 1,784 & & $-2,762$ & 0,007 \\
\hline AS & 6,460 & 1,298 & 0,484 & 4,976 & 0,000 \\
\hline PS & $-0,028$ & 0,048 & $-0,057$ & $-0,588$ & 0,558 \\
\hline $\begin{array}{l}\text { R Multipel } \\
R \text { Square } \\
\text { Adjusted } R \text { Square } \\
\text { Std. error of the Estimate }\end{array}$ & & $\begin{array}{c}0,502 \\
0,252 \\
0,234 \\
4,9461 \\
\end{array}$ & $\begin{array}{l}\text { F-Statistic } \\
\text { Sig. }\end{array}$ & & $\begin{array}{c}14,294 \\
0,000\end{array}$ \\
\hline
\end{tabular}

Sumber: Hasil Olahan Data Penelitian dengan Mempergunakan Program SPSS Version 18.

Berdasarkan Tabel 3 di atas, dapat dikemukakan bahwa nilai koefisien determinan sebesar 25,2 persen dengan nilai F-statistik adalah 14,294 dan probabilitas sebesar 0,000. Selanjutnya, nilai koefisien regressi variabel available slack (AS) sebesar 6,460 dengan nilai t-satistik adalah 4,976 dan probabilitas sebesar 0,000. Dengan demikian dapat dikemukakan bahwa available slack (AS) berpengaruh positip dan signifikan terhadap kinerja perusahaan (KP). Nilai koefisien regressi variabel potential slack (PS) sebesar - 0,028 dengan nilai t-satistik adalah -0,588 dan probabilitas sebesar 0,558. Dengan demikian dapat dikemukakan bahwa variabel potential slack (PS) berpengaruh negatip dan tidak signifikan terhadap kinerja perusahaan (KP).

Rekapitulasi hasil perhitungan pengaruh available slack (AS) dan potential slack (PS) terhadap kinerja perusahaan (KP) berdasarkan current ratio (diatas 200 persen) dapat dilihat pada Tabel 4 berikut ini.

Tabel 4. Rekapitulasi Hasil Penelitian Pengaruh Available Slack dan Potential slack Terhadap Kinerja Perusahaan Berdasarkan Current Ratio (diatas 200 Persen)

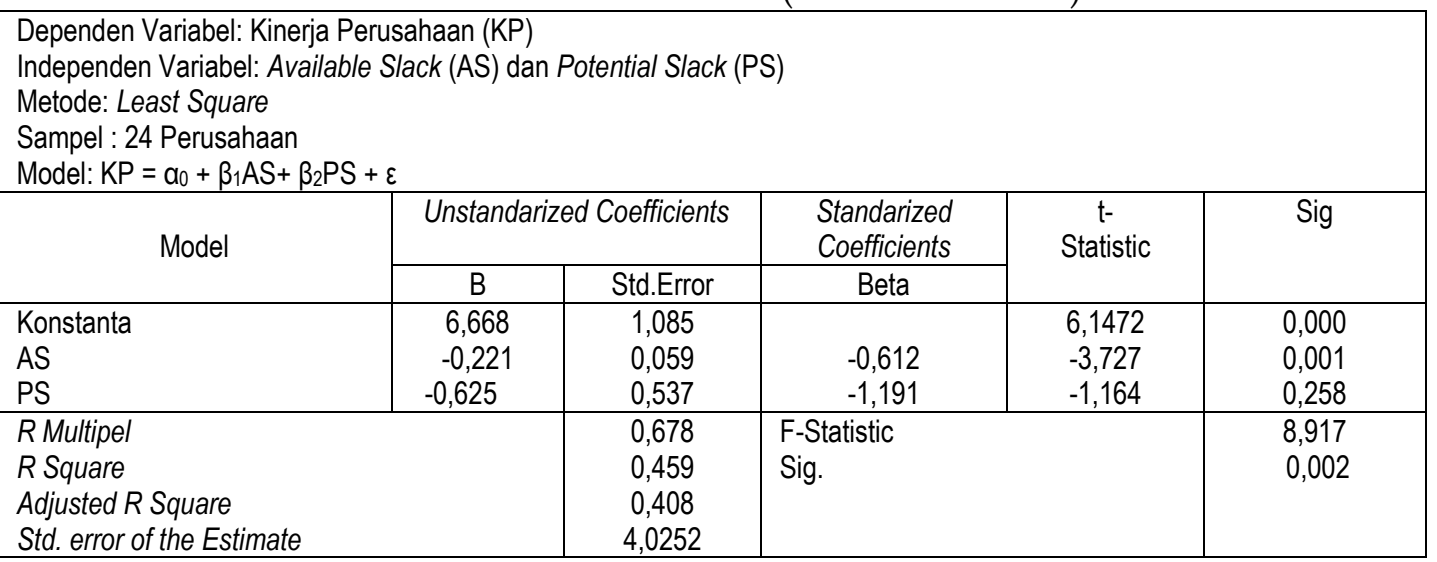

Sumber: Hasil Olahan Data Penelitian dengan Mempergunakan Program SPSS Version 18.

Berdasarkan Tabel 4 di atas, dapat dikemukakan bahwa nilai koefisien determinan sebesar 45,9 persen dengan nilai F-statistik adalah 8,917 dan probabilitas sebesar 0,002. Selanjutnya, nilai koefisien regressi variabel available slack (AS) sebesar -0,221 dengan nilai t-satistik adalah -3,727 dan probabilitas sebesar 0,001. Dengan demikian dapat dikemukakan bahwa available slack (AS) berpengaruh negatip dan signifikan terhadap kinerja perusahaan (KP). Nilai koefisien regressi variabel potential slack (PS) sebesar - 0,625 dengan nilai t-satistik adalah -1,164 dan probabilitas sebesar 0,258. Dengan demikian dapat dikemukakan bahwa potential slack (PS) berpengaruh negatip dan tidak signifikan terhadap kinerja perusahaan (KP).

Dalam literatur manajemen keuangan dikemukakan bahwa ukuran tradisional tentang besaran debt to equity ratio adalah 100 persen. Oleh karena itu, sampel penelitian ini dikelompokkan 
berdasarkan debt to equity ratio menjadi dua kelompok. Kelompok pertama, terdiri dari perusahaanperusahaan yang memiliki debt to equity ratio dibawah 100 persen dan kelompok kedua adalah sampel yang memiliki debt to equity ratio diatas 100 persen.

Rekapitulasi hasil perhitungan pengaruh available slack (AS) dan potential slack (KPS) terhadap kinerja perusahaan (KP) berdasarkan debt to equity ratio dapat dilihat pada Tabel 5 berikut ini.

Tabel 5. Rekapitulasi Hasil Penelitian Pengaruh Available Slack dan Potential slack Terhadap Kinerja Perusahaan Berdasarkan Debt to Equity Ratio (dibawah 100 Persen)

\begin{tabular}{|c|c|c|c|c|c|}
\hline \multicolumn{6}{|c|}{$\begin{array}{l}\text { Dependen Variabel: Kinerja Perusahaan (KP) } \\
\text { Independen Variabel: Available Slack (AS) dan Potential Slack (PS) } \\
\text { Metode: Least Square } \\
\text { Sampel : } 37 \text { Perusahaan } \\
\text { Model: KP }=\alpha_{0}+\beta_{1} A S+\beta_{2} P S+\varepsilon\end{array}$} \\
\hline \multirow[b]{2}{*}{ Model } & \multicolumn{2}{|c|}{ Unstandarized Coefficients } & $\begin{array}{l}\text { Standarized } \\
\text { Coefficients }\end{array}$ & $\begin{array}{c}\text { t- } \\
\text { Statistic }\end{array}$ & Sig \\
\hline & $B$ & Std.Error & Beta & & \\
\hline $\begin{array}{l}\text { Konstanta } \\
\text { AS } \\
\text { PS }\end{array}$ & $\begin{array}{c}4,078 \\
-0,195 \\
3,067\end{array}$ & $\begin{array}{l}1,147 \\
0,147 \\
0,973\end{array}$ & $\begin{array}{l}-0,196 \\
0,465\end{array}$ & $\begin{array}{c}3,554 \\
-1,329 \\
3,153\end{array}$ & $\begin{array}{l}0,001 \\
0,193 \\
0,003\end{array}$ \\
\hline $\begin{array}{l}R \text { Multipel } \\
R \text { Square } \\
\text { Adjusted } R \text { Square } \\
\text { Std. error of the Estimate }\end{array}$ & & $\begin{array}{c}0,511 \\
0,261 \\
0,218 \\
5,8028\end{array}$ & $\begin{array}{l}\text { F-Statistic } \\
\text { Sig. }\end{array}$ & & $\begin{array}{l}6,015 \\
0,006\end{array}$ \\
\hline
\end{tabular}

Sumber: Hasil Olahan Data Penelitian dengan Mempergunakan Program SPSS Version 18.

Berdasarkan Tabel 5 di atas, dapat dikemukakan bahwa nilai koefisien determinan sebesar 26,1 persen dengan nilai F-statistik adalah 6,015 dan probabilitas sebesar 0,006. Selanjutnya, nilai koefisien regressi variabel available slack (AS) sebesar -0,195 dengan nilai t-satistik adalah -1,329 dan probabilitas sebesar 0,193. Dengan demikian dapat dikemukakan bahwa available slack (AS) berpengaruh negatip dan tidak signifikan terhadap kinerja perusahaan (KP). Nilai koefisien regressi variabel potential slack (PS) sebesar 3,067 dengan nilai t-satistik adalah 3,153 dan probabilitas sebesar 0,003. Dengan demikian dapat dikemukakan bahwa potential slack (PS) berpengaruh positip dan signifikan terhadap kinerja perusahaan (KP).

Rekapitulasi hasil perhitungan pengaruh available slack (AS) dan potential slack (PS) terhadap kinerja perusahaan (KP) berdasarkan debt to equity ratio (diatas 100 persen) dapat dilihat pada Tabel 6 berikut ini.

Tabel 6. Rekapitulasi Hasil Penelitian Pengaruh Available Slack dan Potential slack Terhadap Kinerja Perusahaan Berdasarkan Debt to Equity Ratio (diatas 100 Persen)

\begin{tabular}{|c|c|c|c|c|c|}
\hline \multicolumn{6}{|c|}{$\begin{array}{l}\text { Dependen Variabel: Kinerja Perusahaan (KP) } \\
\text { Independen Variabel: Available Slack (AS) dan Potential Slack (PS) } \\
\text { Metode: Least Square } \\
\text { Sampel : } 75 \text { Perusahaan } \\
\text { Model: KP }=\alpha_{0}+\beta_{1} A S+\beta_{2} P S+\varepsilon\end{array}$} \\
\hline \multirow{2}{*}{ Model } & \multicolumn{2}{|c|}{ Unstandarized Coefficients } & Standarized & \multirow{2}{*}{$\begin{array}{c}\mathrm{t}- \\
\text { Statistic }\end{array}$} & \multirow[t]{2}{*}{ Sig } \\
\hline & $B$ & Std.Error & Beta & & \\
\hline Konstanta & 3,646 & 0,601 & & 6,064 & 0,000 \\
\hline & $-0,158$ & 0,074 & $-0,237$ & $-2,132$ & 0,036 \\
\hline & $-0,100$ & 0,045 & $-0,248$ & $-2,236$ & 0,028 \\
\hline R Multipel & & 0,339 & F-Statistic & & 4,664 \\
\hline$R$ Square & & 0,115 & Sig. & & 0,012 \\
\hline Adjusted R Square & & 0,090 & & & \\
\hline Std. error of the Estimate & & 4,7135 & & & \\
\hline
\end{tabular}

Sumber: Hasil Olahan Data Penelitian dengan Mempergunakan Program SPSS Version 18.

Berdasarkan Tabel 6 di atas, dapat dikemukakan bahwa nilai koefisien determinan sebesar 11,5 persen dengan nilai F-statistik adalah 4,664 dan probabilitas sebesar 0,012. Selanjutnya, nilai koefisien regressi variabel available slack (AS) sebesar -0,158 dengan nilai t- 
satistik adalah -2,132 dan probabilitas sebesar 0,036. Dengan demikian dapat dikemukakan bahwa available slack (AS) berpengaruh negatip dan signifikan terhadap kinerja perusahaan (KP). Nilai koefisien regressi variabel potential slack (PS) sebesar -0,100 dengan nilai t-satistik adalah -2,236 dan probabilitas sebesar 0,028. Dengan demikian dapat dikemukakan bahwa potential slack (PS) berpengaruh negatip dan signifikan terhadap kinerja perusahaan (KP).

\section{Pembahasan}

Berdasarkan rekapitulasi hasil penelitian sebagaimana ditunjukkan pada Tabel 2 di atas dapat dikemukakan bahwa available slack (AS) berpengaruh negatip dan signifikan terhadap kinerja perusahaan (KP). Hal ini ditunjukkan oleh nilai koefisien regressi variabel available slack (AS) sebesar -0,165 dengan probabilitas sebesar 0,023. Artinya, setiap peningkatan available slack (AS) sebesar 1 satuan mengakibatkan kinerja perusahaan (KP) turun sebesar 0,165 satuan. Pengaruh negatip available slack (AS) terhadap kinerja perusahaan (KP) menggambarkan bahwa sumberdaya ekstra yang tersedia mendorong manajer melakukan aktivitas dalam memenuhi keinginannya sehingga dapat menurunkan kinerja perusahaan. Oleh karenanya, dalam meningkatkan kinerja perusahaan (KP) perlu diturunkan sumberdaya ekstra yang dimiliki perusahaan.

Selanjutnya, potential slack (PS) berpengaruh negatip dan signifikan terhadap kinerja perusahaan (KP). Hal ini ditunjukkan oleh nilai koefisien regressi variabel potensial slack (PS) sebesar -0,102 dengan probabilitas sebesar 0,044. Artinya, setiap peningkatan potential slack (PS) sebesar 1 satuan mengakibatkan penurunan kinerja perusahaan (KP) sebesar 0,102 satuan. Pengaruh negatip potential slack (PS) terhadap kinerja perusahaan (KP) menggambarkan bahwa kenaikan modal potensial perusahaan akibat perubahan lingkungan dipandang sebagai biaya yang tidak diperlukan perusahaan sehingga dengan slack tersebut mendorong manajer melakukan aktivitas untuk memenuhi keinginannya sehingga dapat menurunkan kinerja perusahaan. Oleh karenanya, dalam meningkatkan kinerja perusahaan (KP) perlu diturunkan modal potensial perusahaan.

Berdasarkan koefisien arah pengaruh available slack (AS) dan potential slack (PS) terhadap kinerja perusahaan (KP) dapat dikemukakan bahwa tidak ada dampak yang berbeda antara available slack (AS) dan potential slack (PS) terhadap kinerja perusahaan (KP). Dengan kata lain, pengaruh available slack (AS) lebih besar daripada dampak potential slack (PS) terhadap kinerja perusahaan (KP). Hal ini dapat dibenarkan disebabkan available slack (AS) menggambarkan sumberdaya perusahaan yang likuid yang dapat dipergunakan untuk memenuhi kewajibannya dengan segera, sementara potential slack (PS) menggambarkan sumberdaya masa depan yang tidak dapat dipergunakan dengan segera.

Analisis dilakukan juga berdasarkan pengelompokan slack. Hasil penelitian menunjukkan bahwa pengaruh available slack (AS) dan potential slack (PS) terhadap kinerja perusahaan (KP) tidak konsisten pada kelompok slack yang rendah. Pada saat slack rendah (current ratio dibawah 200 persen), available slack berpengaruh positip dan signifikan terhadap kinerja perusahaan (KP), sementara potential slack (PS) berpengaruh negatip terhadap kinerja perusahaan (KP) yang walaupun tidak signifikan. Sebaliknya, pada saat slack rendah (debt to equity ratio dibawah 100 persen), available slack (AS) berpengaruh negatip dan tidak signifikan terhadap kinerja perusahaan (KP) dan potential slack (PS) berpengaruh positip dan signifikan terhadap kinerja perusahaan (KP). Artinya, pada kelompok slack tersebut, sumberdaya yang dimiliki perusahaan dipergunakan pimpinan perusahaan untuk meningkatkan kinerja perusahaan $(\mathrm{KP})$. 
Selanjutnya, berdasarkan kelompok slack tinggi (current ratio diatas 200 persen dan debt to equity ratio diatas 100 persen) bahwa pengaruh available slack (AS) dan potential slack (PS) terhadap kinerja perusahaan (KP) tetap negatip. Kondisi ini menggambarkan bahwa semakin besar sumber daya ekstra dan modal potensial yang dimiliki oleh perusahaan mengakibatkan pimpinan perusahaan cenderung mempergunakan sumberdaya tersebut untuk memenuhi kepentingannya sehingga dapat menurunkan kinerja perusahaan. Oleh karenanya, semakin diperlukan tatakelola perusahaan yang baik dalam rangka meningkatkan kinerja perusahaan terutama jika slack tersebut semakin melebihi kebutuhan tertentu dalam menghasilkan barang dan jasa.

\section{Kesimpulan}

\section{KESIMPULAN DAN SARAN}

Berdasarkan hasil analisis dan pembahasan dapat dikemukakan beberapa kesimpulan sebagai berikut:

Pertama, available slack dan potential slack berpengaruh negatip dan signifikan terhadap kinerja perusahaan.

Kedua, semakin besar slack yang dimiliki perusahaan, ada kecenderungan bahwa pimpinan perusahaan cenderung mempergunakan slack tersebut untuk memenuhi kepentingannya.

\section{Saran}

Berdasarkan kesimpulan di atas dapat dikemukakan beberapa saran sebagai berikut:

Pertama, hasil penelitian menunjukkan bahwa available slack dan potential slack berpengaruh negatip terhadap kinerja perusahaan. Artinya, financial slack yang dimiliki perusahaan dapat menurunkan kinerja perusahaan. Oleh karenanya, jika kinerja perusahaan mau ditingkatkan perlu diturunkan slack yang dimiliki sampai pada tingkat yang dibutuhkan.

Kedua, hasil penelitian ini dapat dipergunakan sebagai dasar bagi regulator dalam membuat regulasi untuk meningkatkan kualitas corporate governance korporasi.

Ketiga, diperlukan penelitian lanjutan tentang financial slack dengan membedakan sampel perusahaan atas perusahaan yang menerapkan tatakelola perusahaan yang baik dan tatakelola perusahaan yang tidak baik.

\section{DAFTAR PUSTAKA}

Bergh, D.D. and M.W. Lawless, 1998. Portfolio Restructuring and Limits to Hierarchical Governance: The Effects of Emvironmental Uncertainty and Diversification Strategy, Organization science 9, 87 - 102.

Berle, A. and Means, A. 1932. The Modern Corporation and Private Property, New York: Macmillan.

Bourgeois, J.I. 1981. On the Measurement of Organizational Slack. Academy of Management Review 6, 29 - 39.

Bourgeois, L,J, and Singh, J.V. 1983, Organizational Slack and Political Behavior Among Top Management Teams, Academy of Management Proceedigs, 43 - 47.

Carter, F, 1971. The Behavioral Theory of the Firm and Top-level Corporate Decisions. Administrative Science Quarterly 16, 413 - 428. 
Cyert, R. and March, J., 1963. A Behavioral Theory of the Firm. Englewood Cliffs, N.J.; PrenticeHall.

Daniel, F. and Lohrke, F.T. and Turner, J. R. A. 2004, Slack Resources and Firm Performance: A Meta-Analysis, Journal of Business Research 57, 565 - 574.

Galbraith, J. 1977. Designing Complex Organizations, Addison Publishing. D.C. Hambrick. \& C. Snow. A Conceptual Model of Strategic Decision Making. Academy of Management Best Paper Proceedings. 109 - 112.

Indriantoro, Nur dan Bambang Supomo, 1999. Metodologi Penelitian Bisnis untuk Akuntansi dan Manajemen, Edisi Pertama, BPFE, Yogyakarta.

Institute for Economic and Financial Research, 2011. Indonesian Capital Market Directory, Jakarta.

Jensen, C. M. and Meckling, W., 1976. Theory of the Firm: Managerial Behavior, Agency Costs, and Ownership Structure. Journal of Financial Economics 3, 305 - 360.

Latham, S. and Braun, M.R., 2008. The Performance Implications of Financial Slack During Economic Recession and Recovery: Observations from the Software Industry (2001-2003). Journal of Managerial Issues. 20, 30 - 50.

Lee, Sanghoom, 2011. How Financial Slack Affects Firm Performance: Evidence from US Industrial Firms, Journal of Economic Research 16, 1 - 27.

Lee, Sanghoon, 2012, Corporate Governance, Financial slack and Firm Performance: A Comparative Study between US and UK, Seoul Journal of Business 18, 3 - 23

Litschert, R.J. and Bonham, T.W., 1978. A Conceptual Model of Strategy Formation. Academy of Management Review.3, 211 - 219.

Mohr, L., 1969. Determinants of Innovation in Organizations. American Political Science Review $63,111-126$.

Myers, S. C. and N.S. Maljuf, 1984. Corporate Financing and Investment Decision When Firms Have Information That Investors Do Not Have, Journal of Financial Economics 13, 187 - 221.

Myers, S.C., 1984. The Capital Structure Puzzle, Journal of Finance 39, 575 - 592.

Nohria, N. and Gulati, R., 1966. Is Slack Good or Bad for Innovation? Academy of Management Journal 39, 1245 - 1264.

Penroe, E., 1959. The Theory of the Growth of the Firm, Oxford University Press, Oxford.

Simon, H, 1997. Administrative Behavior: A Study of Decision Making Process in Administrative Organizations, 4th Ed. New York, NY: The Free Press.

Yasai-Ardekani, M., 1986. Structural Adaptations to Environments. Academy of Management Review. 11, 9 - 21. 